\title{
PENGEMBANGAN KOMPETENSI PROFESIONAL GURU BAHASA ARAB MELALUI PENELITIAN TINDAKAN KELAS
}

\author{
Dina Indriana \\ Universitas Islam Negeri Sultan Maulana Hasanuddin Banten \\ J1. Jendral Sudirman No. 30, Serang - Banten 42118 \\ email: dina.indriana@uinbanten.ac.id
}

\begin{abstract}
Ahmad Arifin
Institut Agama Islam Negeri (IAIN) Metro

Jl. Ki Hajar Dewantara, Iringmulyo, Metro Timur, Metro, Lampung 34381

e-mail:arifin@metrouniv.ac.id
\end{abstract}

\begin{abstract}
The problem faced by teachers, primarily Arabic teachers is how to conduct classroom action research correctly. As for the condition of Madrasah Arabic language teachers in the Serang Regency, most do not have an understanding of this. Then the Department of Arabic Language FTK UIN Sultan Maulana Hasanuddin Banten implemented the Community Service Program to facilitate, bridge, and communicate various lecturer resources in the administration of Community Service. This type of dedication research is qualitative field research. The purpose of this activity that researchers often hear and get information about the difficulties of teachers when going to conduct classroom action research $(C A R)$. Based on this, the researchers conducted community service, especially Madrasah Arabic language teachers in the Serang Regency for assistance, training, workshops, monitoring of the implementation of CAR. From the results of dedication shows that the learning process is still centered on the teacher (teacher center). Doing PTK by the teacher will be able to improve student learning outcomes. The researcher's recommendations are: 1) Arabic teachers should always conduct Classroom Action Research. 2) Adjusting the use of methods in learning with the material, learning objectives, and age of students. 3) The teacher can use learning media. 4) Teachers in teaching must feel happy and cheerful. 5) The use of the time that must be considered.
\end{abstract}

Keywords: Arabic Teacher; Professional; Classroom Action Research. 


\begin{abstract}
Abstrak
Permasalahan yang dihadapi oleh guru, khususnya guru bahasa Arab adalah bagaimana melakukan penelitian tindakan kelas dengan benar. Adapun kondisi guru bahasa Arab madrasah di Kabupaten Serang sebagian besar belum memiliki pemahaman tentang hal tersebut. Maka Jurusan Pendidikan Bahasa Arab FTK UIN Sultan Maulana Hasanuddin Banten melaksanakan Program Pengabdian Masyarakat guna memfasilitasi, menjembatani hingga mengomunikasikan berbagai sumber daya dosen dalam penyelenggaraan Pengabdian Kepada Masyarakat. Jenis penelitian pengabdian ini adalah penelitian kualitatif lapangan. Tujuan diadakannya kegiatan ini, bahwa peneliti sering mendengar dan mendapatkan informasi tentang kesulitan guru ketika akan melakukan penelitian tindakan kelas (PTK). Berdasarkan hal tersebut maka peneliti mengadakan pengabdian kepada masyarakat khususnya guru bahasa Arab Madrasah di Kabupaten Serang untuk pendampingan, pelatihan, workshop, monitoring tentang pelaksanaan PTK. Dari hasil pengabdian menunjukkan bahwa proses pembelajaran masih berpusat kepada guru (teacher center). Dilakukannya PTK oleh guru akan dapat meningkatkan hasil belajar peserta didik. Adapun rekomendasi peneliti yaitu: 1) Hendaknya guru bahasa Arab selalu melakukan Penelitian Tindakan Kelas. 2) Penyesuaian penggunaan metode dalam pembelajaran dengan materi, tujuan pembelajaran dan usia peserta didik. 3) Guru mampu menggunakan media pembelajaran. 4) Guru dalam mengajar harus merasa senang dan ceria. 5) Penggunaan waktu yang harus diperhatikan.
\end{abstract}

Kata Kunci: Guru Bahasa Arab; Profesional; PTK.

\title{
A. Pendahuluan
}

Pengajar yang baik yaitu pengajar yang dapat mengajarkan materi dengan menggunakan berbagai metode pembelajaran bahasa Arab dengan benar dan tepat. Guru yang mampu mengendalikan kelas dan dapat memakai media pembelajaran dengan benar sesuai dengan tujuan yang hendak dicapai, dan guru yang mampu menguasai materi hingga ia mampu disebut sebagai guru profesional. Menjadi guru profesional tidak mudah. Namun sebagai guru harus selalu berusaha dan mencoba agar mampu menjadi seorang guru profesional.

Dalam pembelajaran di kelas sebaiknya guru menggunakan metode diskusi untuk beberapa materi. Dengan berdiskusi peserta didik akan mendapatkan pengetahuan dari teman sebaya. Guru tidak lagi mendominasi kegiatan interaksi edukatif, berdiri di depan kelas, memberikan penjelasan 
sampai akhir pelajaran. Dengan seperti ini peserta didik akan merasakan jenuh dalam belajar. ${ }^{1}$

Salah satu guru dapat dikatakan profesional adalah ketika guru dapat melakukan penelitian tindakan kelas (PTK). Dimana problematika yang selalu ditemui oleh seorang pengajar dalam kelas dapat diteliti, supaya menemukan solusi yang sesuai. Dalam pelaksanaan PTK guru harus mampu merancang media yang akan digunakan. Media terbaik yang dapat diterapkan pada suatu pembelajaran yaitu media yang mempunyai tingkat hubungan dengan materi, tujuan, dan karakteristik siswa. ${ }^{2}$

Penelitian tindakan kelas (PTK) sebagai salah satu bentuk penelitian yang banyak dilaksanakan oleh tenaga pengajar, membawa banyak manfaat, di antaranya yaitu membantu pengajar untuk memperbaiki kualitas proses belajar mengajar dalam kelas, membawa banyak manfaat di antaranya memperbaiki proses pembelajaran sehingga menjadi pembelajaran yang berkualitas, meningkatkan profesionalisme guru serta guru dapat mengembangkan pengetahuan dan keterampilannya. Dengan melakukan penelitian tindakan kelas guru menjadi terbiasa meneliti dan menulis sehingga mendapatkan manfaat.

Permasalahan bagi guru bahasa Arab Madrasah di kabupaten Serang di antaranya kenaikan pangkat guru yang harus membuat penelitian, namun mereka belum memahami secara mendalam bagaimana PTK dilakukan. Penerapan Peraturan Menteri Pendayagunaan Aparatur Negara dan Reformasi Birokrasi Republik Indonesia No. 16 Tahun 2009 mengenai Jabatan Fungsional Guru berimbas pada kurang siapnya guru mengacapi peraturan menteri tersebut. Aturan itu sudah diberlakukan mulai bulan Oktober 2013. Diantara syarat untuk kenaikan pangkat guru, guru harus membuat karya ilmiah. Dan Siantar karya ilmiah yang populer di kalangan guru diantaranya adalah Penelitian Tindakan Kelas (PTK).

Adapun PTK termasuk karya ilmiah yang memiliki nilai angka kridit yang cukup tinggi dalam penilaiannya. PTK juga mempunyai kaitan dengan tugas seorang pengajar dalam pembelajaran di kelas. Hal itu ditambah bahwa dalam proses penelitian PTK, saat guru sebagai pengajar juga dapat bertindak

\footnotetext{
${ }^{1}$ Syaiful Bahri Djamarah, Guru dan Anak Didik dalam Interaksi Edukatif (Jakarta: Rineka Cipta, 2000), h. 157.

${ }^{2}$ Dina Indriana, Mengajar Efektif dengan Media Pengajaran (Yogyakarta: Diandra Kreatif, 2018), h. 86.
} 
sebagai peneliti. Namun dalam realita pelaksanaan PTK, guru kesulitan dalam menjalani prosesnya karena kurang mengerti prosedur PTK yang benar. Maka wajar jikalau beberapa guru terhambat dalam menerapkan kegiatan pengembangan profesi tersebut.

Maka dari permasalahan tersebut jurusan Pendidikan Bahasa Arab. Adapun kegiatan yang UIN Sultan Maulana Hasanuddin Banten akan mengadakan pendampingan bagi guru bahasa Arab madrasah dalam melakukan penelitian tindakan kelas. Adapun kegiatan tersebut diawali dengan pelaksanaan Workshop atau pendidikan pelatihan, pendampingan bagi guru bahasa Arab madrasah, monitoring, dan evaluasi. Diharapkan kegiatan tersebut dapat berjalan dengan lancar.

Salah satu tujuan kegiatan tersebut yaitu memotivasi para guru agar mereka melakukan kegiatan penelitian/ PTK dikarenakan beberapa alasan untuk bisa mengadakan pengembangan potensi peserta didik dalam kelas. Jika guru dapat melaksanakan penelitian di kelasnya maka guru akan mengetahui potensi peserta didik, pengajar menjadi makin merasa adanya kedekatan dengan peserta didiknya dan terjadilah proses interaksi antara pengajar dan peserta didik. Diharapkan dengan dilakukannya penelitian tindakan kelas dapat meningkatkan keberlangsungan proses pembelajaran di kelas yang berkualitas. Dengan demikian, terasahlah sisi profesionalismenya sebagai seorang guru.

Jenis penelitian pengabdian ini adalah penelitian kualitatif lapangan. Tujuan diadakannya pengabdian kepada masyarakat ini bahwa peneliti sering mendengar dan mendapatkan informasi tentang kesulitan guru ketika akan melakukan penelitian tindakan kelas (PTK). Berdasarkan hal tersebut maka peneliti berkeinginan mengadakan pengabdian kepada masyarakat khususnya guru bahasa Arab Madrasah di Kabupaten Serang untuk mengadakan pendampingan, pelatihan, workshop, monitoring tentang pelaksanaan PTK. Hasilnya adalah agar guru dapat melakukan PTK dengan baik.

Adapun yayasan Al-Khairiyah mengalami transformasi dan modernisasi di masing-masing yayasan Al-Khairiyah yang berada di provinsi Banten. Yayasan Al-Khairiyah yang berada di kabupaten serang mengalami perkembangan sangat maju. Untuk mengimbangi hal tersebut maka kami dari jurusan PBA UIN SMH Banten ikut serta memajukkan perkembangan yayasan Al-Khairiyah dengan mengadakan pendampingan dan pelatihan bagi guru bahasa Arab Madrasah. 
Para guru masih banyak yang kebingungan melakukan PTK yang dilaksanakan dalam kelas. Mereka merasa Kebingungan bertambah lagi setelah munculnya kebijakan agar seorang pengajar mampu melaksanakan penelitian tindakan kelas di kelas yang ia ajar, sehingga tidak mengganggu jam mengajar. Untuk menjembatani dan membantu para guru dalam melakukan penelitian maka jurusan Pendidikan bahasa Arab UIN SMH Banten bermaksud mengadakan pendidikan dan pelatihan/ workshop penelitian tindakan kelas bagi guru bahasa Arab madrasah yang ada di Kabupaten Serang.

Salah satu komponen terpenting dalam kegiatan pembelajaran adalah guru. Seorang guru wajib berusaha untuk menjadi guru dengan meningkatkan potensi dan kualitas dirinya, sehingga guru dapat menjadi seorang guru yang profesional di bidangnya. Menurut para ahli yang dimaksud dengan guru profesional merupakan semua guru yang memiliki wewenang serta bertanggung jawab pada pendidikan peserta didiknya di sekolahan maupun di luar sekolahan.

Guru madrasah biasanya dikenal dengan guru yang acuh yang tidak bisa menjadi guru yang profesional. Paradigma inilah yang harus dihilangkan dari seorang guru madrasah. Guru madrasah harus mampu mengajar dengan baik, mampu menggunakan media dan teknologi yang modern, mampu menggunakan metode pengajaran yang sesuai dengan tujuan pembelajarannya. Dan guru madrasah juga harus mampu menciptakan lingkungan pembelajaran yang bersih dan nyaman.

Salah satu kriteria menjadi guru profesional yaitu mampu melaksanakan penelitian. Penelitian tindakan kelas merupakan suatu pencermatan terhadap proses kegiatan belajar mengajar yang berupa suatu tindakan yang sengaja ditampilkan dan terjadi pada suatu kelas secara bersamaan. ${ }^{3}$ Tindakan itu diberikan oleh pengajar ataupun dengan petunjuk dari pengajar yang dilaksanakan oleh siswa. Menurut Aqib ada beberapa alasan menggunakan PTK yaitu karena PTK terlihat sangat kondusif untuk menjadikan pengajar peka dan tanggap pada dinamika proses pembelajaran yang ada dalam kelas.

Setelah diadakannya pendampingan dan workshop penelitian tindakan kelas bagi guru bahasa Arab Madrasah dapat meningkatkan kualitas guru dan

${ }^{3}$ Zainal Aqib, Penelitian Tindakan Kelas untuk Guru (Bandung: Yrama Widya, 2006), h. 35. 
profesionalisme guru bahasa Arab madrasah di yayasan Al-Khairiyah Kabupaten Serang dan di berbagai sekolahan/ madrasah di Kabupaten Serang

Workshop PTK yang peneliti adakan di kampus 2 UIN SMH Banten pada Jurusan Pendidikan Bahasa Arab. Peserta terdiri dari 20 peserta dari berbagai sekolah di kabupaten Serang. Namun peneliti melakukan pendampingan di sekolah Al-Khairiyah kabupaten Serang.

Setelah mengikuti kegiatan workshop yang diadakan di UIN SMH Banten peneliti mengadakan pendampingan ke sekolah untuk melihat bagaimana pelaksanaan pembelajaran berlangsung. Mulai dari merencanakan kegiatan penelitian, menemukan masalah, menggunakan siklus hingga ke tahap pelaksanaan PTK.

Pada penelitian ini didukung oleh beberapa penelitian-penelitian terdahulu. Adapun penelitian relevan yang berkaitan dengan penelitian ini yaitu di antaranya sebagai berikut: Artikel jurnal dengan judul: "Upaya Meningkatkan Kompetensi Guru Melalui Pelatihan Penelitian Tindakan Kelas" yang ditulis oleh Happy Fitria, Muhammad Kristiawan, Nur Rahmat. Di dalam jurnal tersebut penulis ingin meningkatkan kompetensi guru SD dan SMP Negeri ataupun Swasta yang ada di Kabupaten Ogan Ilir, Sumatera Selatan. Dalam hasil akhirnya dikemukakan bahwa proses pelatihan memberi manfaat bagi guru, dapat meningkatkan pemahaman pada Penelitian Tindakan Kelas, menumbuhkan motivasi dalam penyusunan PTK dan melaksanakannya, serta bagi sekolah dapat meningkatkan kinerja melalui peningkatan profesionalisme guru. ${ }^{4}$ Artikel jurnal selanjutnya yang ditulis oleh: Syamsiarna Nappu dan Ratna Dewi, dengan judul "Peningkatan Kemampuan Guru dalam Melaksanakan Penelitian Tindakan Kelas". Adapun pengabdian masyarakat tersebut bertujuan untuk memotivasi para guru di SMP Negeri 23 Makassar untuk melakukan penelitian tindakan kelas dan membantu mereka meningkatkan kompetensi. Metode yang dipergunakan yaitu ceramah, diskusi, tanya jawab, dan pelatihan. Output dari kegiatan tersebut yaitu: 1) guru termotivasi dan bersedia untuk mengembangkan inovasi pembelajaran di sekolah melalui penelitian tindakan kelas dan 2) para

\footnotetext{
${ }^{4}$ Happy Fitria, Muhammad Kristiawan, dan Nur Rahmat, “Upaya Meningkatkan Kompetensi Guru Melalui Pelatihan Penelitian Tindakan Kelas," Abdimas UNWAHAS 4, no. 1 (2019), https://doi.org/10.31942/abd.v4i1.2690.
} 
guru membuat proposal serta melakukan penelitian tindakan kelas. ${ }^{5}$ Dan adapun artikel jurnal selanjutnya dengan judul: "Pelatihan Penelitian Tindakan Kelas Bagi Guru SD Negeri Guwosari” yang ditulis oleh Padrul Jana dan Bayu Pamungkas. Adapun kegiatan pelatihan tersebut bertujuan untuk mendampingi guru dalam hal penulisan proposal penelitian tindakan kelas, pelaksanaan penelitian tindakan kelas dan pelaporan hasil penelitian tindakan kelas. Metode yang digunakan dalam kegiatan tersebut yaitu klasikal dan diskusi yang meliputi beberapa tahapan yaitu penyampaian materi sistematika penulisan proposal, teknis pelaksanaan penelitian, klinis penyusunan proposal, pendampingan pelaksanaan penelitian dan penyusunan laporan akhir. Hasil yang dicapai dalam kegiatan tersebut adalah bertambahnya pemahaman guru pada PTK, hasil penelitian diharapkan dapat digunakan sebagai perbaikan, rekomendasi model pembelajaran dan menambah angka kredit peneliti. ${ }^{6}$

\section{B. Kajian Teori}

\section{Tugas Guru dalam Pembelajaran}

Belajar merupakan sebuah proses pelik, rumit, sulit yang terjadi pada diri peserta didik sepanjang masa. Interaksi antara seseorang dengan lingkungan adalah beberapa sebab munculnya permasalahan dalam belajar. Terjadinya interaksi saat proses pembelajaran sangat mempengaruhi keberhasilan diri siswa. Adanya perkembangan ilmu teknologi dan ilmu pengetahuan mendorong usaha-usaha pembaharuan pada kegiatan pembelajaran. ${ }^{7}$ Guru dituntut untuk selalu meningkatkan kualitas dirinya mulai dari kemampuan merencanakan pembelajaran, kemampuan menggunakan metode yang tepat, kemampuan dalam penggunaan media pembelajaran yang berbasiskan teknologi, serta guru mampu membuat sendiri dan merancang media pembelajaran. Oleh karena itu pada pelaksanaan pembelajaran di kelas harus dapat:

\footnotetext{
${ }^{5}$ Syamsiarna Nappu, Ratna Dewi, dan Herlina Daddi, “Peningkatan Kemampuan Guru dalam Melaksanakan Penelitian Tindakan Kelas," Jurnal Dedikasi 21, no. 1 (2019): 5, https://ojs.unm.ac.id/dedikasi/article/view/9431.

${ }^{6}$ Padrul Jana dan Bayu Pamungkas, "Pelatihan Penelitian Tindakan Kelas Bagi Guru SD Negeri Guwosari," Abdimas Dewantara 1, no. 1 (2018): 39-46, https://doi.org/10.30738/ad.v1i1.2289.

${ }^{7}$ Azhar Arsyad, Media Pembelajaran (Jakarta: Raja Grafindo, 2007), h. 4.
} 
1) Guru mampu mengelola kelas dengan baik sehingga siswa ketika mengikuti kegiatan pembelajaran merasa senang dan nyaman.

2) Guru harus dapat menggunakan alat komunikasi agar efektif;

3) Guru harus mampu memakai metode pengajaran yang sesuai dengan media pembelajaran;

4) Guru harus mampu berinovasi dalam kegiatan pembelajaran.

Kesuksesan guru bukanlah diukur hanya dari kehadiran rutinan saja, namun bagaimana ia mampu mendinamiskan, mensupport, menggugah, membuat tantangan pada peserta didiknya untuk berpikiran maju yang pada akhirnya melampaui tujuan pembelajarannya. ${ }^{8}$ Akan tetapi proses untuk melampaui tujuan pembelajaran tersebut tidaklah mudah. Terdapat banyak permasalahan yang harus mampu diselesaikan oleh guru yaitu salah satunya dengan langkah-langkah penelitian ilmiah yang bisa dipertanggung jawabkan.

\section{Pengertian Penelitian Tindakan Kelas}

\section{a) Pengertian PTK (Penelitian Tindakan Kelas)}

Adapun pengertian PTK secara mudah akan diuraikan dalam tiga pengertian konsep sebagai berikut:

1) Penelitian merupakan kegiatan mengamati sebuah hal tertentu dengan menempuh metodologi ilmiah dengan cara menghimpun data-data dan menganalisa untuk menyelesaikan masalah tertentu.

2) Tindakan yaitu kegiatan yang dimaksudkan untuk dilaksanakan dengan maksud khusus yang berupa siklus aktivitas dengan tujuan untuk peningkatan mutu atau kualitas proses pembelajaran.

3) Kelas ialah sekelompok peserta didik yang ada pada waktu yang sama menerima suatu pelajaran yang sama dari seorang pengajar. ${ }^{9}$

Sedangkan menurut pendapat Hopkins PTK adalah suatu bentuk kajian reflektif yang dilaksanakan oleh pelaku tindakan untuk meningkatkan kestabilan rasional dari tindakan-tindakannya dalam melakukan tugas dan memperdalam pada keadaan praktek pembelajaran. ${ }^{10}$

\footnotetext{
${ }^{8}$ Masnur Muslich, Melaksanakan PTK (Penelitian Tindakan Kelas) (Jakarta: Bumi Aksara, 2009), h. 78.

${ }^{9}$ Kunandar, Langkah Mudah Penelitian Tindakan Kelas (Jakarta: PT. Rajawali Pers, 2011), h. 45.

${ }^{10}$ Masnur Muslich, Melaksanakan PTK Itu Mudah (Jakarta: Bumi Aksara, 2011), h.
} 8. 


\section{b) Langkah-Langkah Penelitian Tindakan Kelas}

Sebelum melaksanakan penyusunan rencana Penelitian Tindakan Kelas hendaknya kegiatan-kegiatan yang perlu dilaksanakan adalah sebagai berikut: ${ }^{11}$

1. Identifikasi masalah

Langkah awal yaitu identifikasi masalah perlu dilakukan adalah dengan menentukan bidang fokus suatu masalah yang hendak diteliti, dilanjutkan pada pokok masalah serta pengembangan masalah. Contohnya penerapan identifikasi dalam segi pembelajaran yaitu pemilihan fokus masalah atau kegiatan yang ingin dipilih didasarkan pada urgensi dan manfaatnya, serta kemampuan diri dalam melaksanakan pemecahan masalah tersebut.

2. Pengumpulan data

Langkah selanjutnya adalah aktivitas mengumpulkan data yang berkaitan dengan proses kegiatan yang merupakan fokus permasalahan. Contohnya adalah masalah yang menjadi pokok yaitu pembelajaran yang menekankan proses kegiatan siswa dalam pengajaran atau biasa disebut dengan pembelajaran kooperatif. Pada langkah tersebut pengajar mengamati, mengumpulkan berkas, menilik proses pengajaran dan keberhasilan pengajaran yang terkait dengan pemecahan problem yang ditemui. Selain hal tersebut, guru juga perlu memperhatikan beberapa topik apa saja yang menjadi pembahasan, langkah pembelajaran, dan sumber pembelajaran.

3. Analisis dan interpretasi data

Langkah setelah dilakukan pengumpulan data, hasilnya dianalisa secara kualitatif, dijabarkan, diperbandingkan, diklasifikasikan, dipadukan, kemudian diruntutkan secara teratur. Adapun hasil analisanya diberikan interpretasi ke dalam arti umum ataupun khusus.

4. Solusi permasalahan

Langkah terakhir dalam tahap ini yaitu pencarian solusi sebagai upaya untuk mencarikan ataupun mengadakan pengembangan tentang perbaikan yang ada. Hal tersebut bisa dilaksanakan dengan mengulas teori-teori dan beberapa hasil

${ }^{11}$ Suharsimi Arikunto, Suhardjono, dan Supardi, Penelitian Tindakan Kelas (Jakarta: Bumi Aksara, 2006), h. 98. 
penelitian terdahulu yang selaras, mendiskusikan dengan rekan kerja ataupun langsung dengan ahlinya, bahkan pengajar juga bisa menggalinya dari pengalaman pribadi. Tindakan perbaikan tersebut harus berdasarkan kemampuan dan komitmen pengajar sebagai seorang peneliti yang melaksanakannya, kemampuan peserta didik, fasilitas lembaga, serta iklim pembelajaran di lembaga.

Penelitian Tindakan Kelas begitu berpotensi besar untuk membantu peningkatan proses belajar mengajar jika diterapkan sesuai dengan prosedurnya. Artinya pihak yang ikut terlibat (pengajar) berusaha dengan sungguh untuk mengembangkan kecakapan dalam menemukan dan memecahakan permasalahan proses belajar mengajar melalui sikap positif yang paling tidak mampu memperbaiki problematika atau situasi. Pada akhirnya peneliti mengamati proses pelaksanaannya sesuai kaidah penelitian tindakan, yang bertujuan mengukur tingkatan keberhasilan pembelajaran di suatu lembaga.

\section{Hasil dan Pembahasan}

\section{Workshop Penelitian Tindakan Kelas}

Kegiatan workshop yang peneliti adakan adalah tentang pendampingan kepada guru bahasa Arab agar mereka memahami bagaimana pelaksanaan PTK di kelas. PTK adalah suatu penelitian yang hanya bisa dilaksanakan oleh pengajar ketika ia mengajar. Permasalahan yang muncul adalah permasalahan yang terjadi di dalam kelas bukan di luar kelas. Mengenai hal tersebut, guru harus memahami benar adanya permasalahan yang ada. Jika guru tidak peka terhadap permasalahan yang ada maka PTK tidak dapat dilakukan.

Selama peneliti melakukan pendampingan di beberapa sekolah di Kabupaten Serang mayoritas guru kurang memahami masalah yang ada di kelasnya. Tujuan dilaksanakannya Penelitian Tindakan Kelas tersebut untuk melakukan perbaikan pada proses belajar mengajar. Dengan adanya kegiatan workshop maka guru memahami bagaimana sebenarnya pelaksanaan PTK dilakukan. Materi Penelitian Tindakan Kelas disampaikan oleh bapak Khaeroni, M.Si.

Workshop PTK diawali dengan: 
a) Mencari permasalahan yang ada di dalam kelas. Setelah guru menemukan beberapa masalah. Maka dicari dan diputuskan masalah yang sangat perlu untuk segera diatasi;

b) Setelah menemukan masalah maka guru dianjurkan untuk merumuskan masalah penelitian. Perumusan masalah harus diawali dengan kalimat tanya;

c) Kemudian guru harus menemukan jawaban dari rumusan masalah yang dijabarkan dalam tujuan penelitian;

d) Kemudian guru diminta untuk mencocokkan alat pengumpul data dengan pertanyaan atau rumusan masalah.

Dalam penelitian tindakan kelas dikenal dengan istilah siklus yaitu bagaimana peneliti melakukan penelitian. Ketika akan melakukan PTK guru harus mengetahui dengan mendalam terkait materi apa yang harus disampaikan oleh pengajar beserta waktu dan tata caranya. Bagaimana guru dapat menciptakan ruang kerja untuk dapat mengeksplorasi hal-hal yang dipahaminya. Dengan melakukan siklus tindakan merupakan satu cara yang sangat efektif yang bisa digunakan oleh guru untuk mewujudkan refleksi diri yang cukup melekat dengan kebutuhan praktek sehari-hari.

Dalam materi workshop guru bahasa Arab diminta untuk berdiskusi tentang siklus tindakan yang akan mereka lakukan. Untuk memutuskan berapa siklus yang akan mereka lakukan hendaknya mereka melakukan minimal dua siklus terlebih dahulu. Atau melakukan siklus pertama dengan mendapatkan hasil dari tindakan siklus pertama. Jika hasilnya kurang bagus hendaknya mereka melakukan siklus selanjutnya.

\section{Monitoring Pelaksanaan Pembelajaran Di Sekolah/Madrasah}

Setelah peserta mengikuti workshop PTK mereka lalu mengaplikasikan ke dalam kegiatan pembelajaran. Guru mendapatkan masalah dalam pembelajaran. Salah satu masalah yang dihadapi oleh guru rata rata adalah bahwa peserta didik kurang semangat mengikuti materi Bahasa Arab.

Dari masalah tersebut maka guru mencari hipotesis bahwa yang melatarbelakangi peserta didik adalah jam pelajaran materi bahasa Arab yang berada di siang hari, peserta didik kurang memahami mufrodat/ kosakata bahasa Arab, guru mengajar sangat menjenuhkan karena 
menggunakan metode ceramah, peserta didik sering diberikan tugas yang sangat banyak. ${ }^{12}$

Dalam kegiatan pembelajaran guru harus memperhatikan hal tersebut di atas sehingga dapat diatasi dan mencari solusi yang tepat. Bebera hal yang bisa diatasi oleh seorang pengajar yaitu penggunaan metode yang tepat dengan tujuan belajar mengajar mata pelajaran bahasa Arab. Guru harus mampu membuat pertimbangan terkait hal berikut:

a) Penggunaan metode selalu berorientasi pada tujuan pembelajaran.

b) Guru tidak memakai satu metode yang monoton.

c) Sering memakai kombinasi berbagai metode.

d) Pemilihan metode harus disesuaikan dengan usia peserta didik.

e) Memperhatikan kondisi dengan beberapa keadaan kelas.

f) Kualitas dan kuantitas fasilitas yang disediakan.

g) Kepribadian pengajar dan kemampuannya saat menyampaikan materi.

Penggunaan metode pembelajaran sangat erat hubungannya dengan asas-asas belajar. Kerelevansian metode pembelajaran dan prinsip-prinsip pembelajaran akan dapat membangkitkan gairah dan semangat peserta didik.

Hubungan yang erat yaitu metode pembelajaran dengan motivasi peserta didik, metode pembelajaran dan aktivitas peserta didik, metode pembelajaran dengan perbedaan individu, metode pembelajaran dan umpan balik, metode pembelajaran dan pengalihan, dan metode pembelajaran dan pemahaman psikis dan psikologis.

Aktivitas yang dilakukan guru di dalam kelas yaitu pengajar menyampaikan materi pelajaran berupa suatu konsep, pengajar menampilkan permasalahan atau pertanyaan atau tugas pada peserta didik, guru memberikan bantuan mempelajari materi yang diberikan atau memecahkan permasalahan, memberi peluang pada siswa untuk mengajukan pertanyaan, mengusahakan sumber belajar yang dibutuhkan oleh peserta didik, memberikan bantuan dan bimbingan belajar, mendorong motivasi belajar, menggunakan berbagai metode dan media, memberikan nilai dan memonitoring hasil evaluasi peserta didik dan menjabarkan terlaksananya tujuan pembelajaran dan menyimpulkannya serta membuat rencana tindak lanjut.

\footnotetext{
${ }^{12}$ Wawancara dengan Fahmi Peserta didik MTs Al-Kahiriyah Serang Banten
} 


\section{Pelaksanaan Pendampingan di Sekolah/ Madrasah}

Pelaksanaan pendampingan peneliti lakukan adalah :

a) Membantu guru mengidentifikasi permasalahan dalam kelas.

b) Merumuskan masalah agar PTK mudah dilakukan.

c) Mencari dan memilih alat pengumpul data agar alat pengumpul data yang digunakan sesuai dengan kebutuhan.

d) Mengolah dan menganalisis data setelah PTK selesai dilakukan.

Hasil dari pendampingan bahwa guru merasa puas dan senang ketika mereka mampu dan bisa membuat proposal Penelitian Tindakan Kelas (PTK) dengan benar.

Proses pembelajaran bahasa Arab di kelas yang dilaksanakan oleh pengajar bahasa Arab adalah sebagai berikut:

1) Pengajar memberi rangsangan pada siswa untuk bertanya mengenai materi sebelumnya. Dalam pembelajaran bahasa Arab pengajar diharapkan mampu menguasai kelas dengan baik.

2) Guru membagi kelompok menjadi beberapa tim yang tiap tim beranggotakan kurang lebih antara empat hingga lima siswa. Tujuan diadakannya duduk berkelompok adalah agar peserta didik saling diskusi dan memberikan informasi tentang materi yang mereka terima.

3) Setiap kelompok berdiskusi dengan didampingi oleh guru kelas. Pada saat belajar kelompok guru berfungsi sebagai fasilitator.

Salah satu keberhasilan dalam PTK adalah pencarian data dari gerbang luar sekolah. Dimana guru melakukan observasi dan wawancara kepada kedua orang peserta didik. Banyak guru bahasa Arab yang ketika mereka melakukan penelitian telah menyusun rumusan masalah yang difokuskan secara tajam pada aspek kurikulum, interaksi kelas, pengelolaan kelas, penilaian hasil belajar, dan cakupan pemahaman peserta didik. Namun mereka melupakan dan cenderung tidak melibatkan orang tua ke dalam proses refleksi. ${ }^{13}$

Ruang kelas bukanlah sistem tertutup sehingga menerima perubahan dan evaluasi dengan mempertimbangkan faktor yang meskipun tidak hadir secara fisik, dapat menimbulkan pengaruh yang luar

${ }^{13}$ Vivienne Marie Baumfield, Elaine Hall, dan Kate Wall, Action Research In the Classroom: Penelitian Tindakan Kelas, trans. oleh Saifuddin Zuhri Qudsy (Yogyakart: Pustaka Pelajar, 2009), h. 172. 
biasa terhadap interaksi dan hasil penelitian. Dalam melibatkan orangtua untuk kegiatan refleksi maka ada tiga hal yang harus dilakukan yaitu:

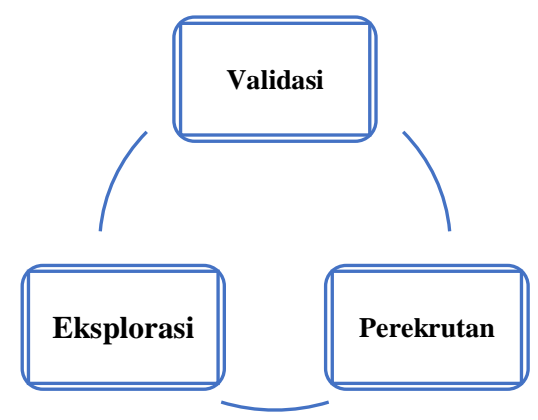

Dalam kegiatan validasi peneliti hendaknya mengajukan pertanyaan "bagaimana kita melakukannya?" Dalam hal ini peneliti perlu membekali orang tua sasaran peneliti tentang informasi penelitian dilakukan sehingga peneliti mendapatkan respon dari orang tua peserta didiknya. Peneliti akan menggunakan alat pengumpulan data dengan kuesioner terstruktur.

Dalam perekrutan peneliti akan meminta kepada orang tua untuk sigap pada urusan kegiatan belajar mengajar, yaitu dengan mengajukan suatu pertanyaan "apakah yang bisa kita lakukan secara bersama?" Dalam melakukan penelitian guru harus melibatkan orang tua agar ia mengetahui orang tua yang mendukung proses pembelajaran anaknya melalui partisipasi di rumah atau di sekolah. Dampak evaluasi ini begitu memberikan pengaruh pada hasil belajar siswa. Dimana guru harus menjalin komunikasi dengan orang tua untuk memberikan informasi tentang perkembangan peserta didiknya.

Dalam eksplorasi, peneliti dapat mengajukan pertanyaan "apakah yang mungkin kita lakukan?" dalam melakukan penelitian tidak semua orang tua mau terlibat. Sebagian orang tua mau bekerja sama dengan peneliti untuk mendapatkan hasil penelitian yang lebih baik, namun sebagian lain terdapat yang tidak berkehendak untuk diajak bekerja sama dengan alasan kesibukan dan lain sebagainya. Dalam hal ini maka seorang peneliti memerlukan alat penelitian yang lebih terbuka semisal kelompok fokus dan wawancara sedangkan peran orang tua di dalam proses penelitiannya cenderung lebih aktif. 


\section{Simpulan}

Dari hasil pengabdian yang peneliti lakukan bahwa guru bahasa Arab dalam mengajarkan bahasa Arab masih berpusat kepada guru (teacher center). Dengan dilakukannya Penelitian Tindakan Kelas (PTK) oleh guru bahasa Arab akan bisa memberikan peningkatan hasil belajar siswa. Sedangkan dari hasil pengabdian kepada masyarakat yang peneliti lakukan ada beberapa rekomendasi yang ingin peneliti utarakan kepada guru bahasa Arab yang ada di Yayasan Al-Khairiyah Pontang Serang Banten, yaitu:

1) Hendaknya guru bahasa Arab selalu melakukan Penelitian Tindakan Kelas, jika dirasa ada permasalahan yang muncul di kelasnya, agar mampu memberikan peningkatan hasil belajar siswa.

2) Penggunaan metode dalam belajar mengajar bahasa Arab harus menyesuaikan pada materi, tujuan dan usia peserta didik.

3) Hendaknya guru dalam mengajar bahasa Arab memakai media.

4) Guru dalam proses pengajaran hendaknya merasa senang dan ceria.

5) Penggunaan waktu dalam belajar bahasa Arab juga harus diperhatikan. 


\section{Daftar Pustaka}

Aqib, Zainal. Penelitian Tindakan Kelas untuk Guru. Bandung: Yrama Widya, 2006.

Arikunto, Suharsimi, Suhardjono, dan Supardi. Penelitian Tindakan Kelas. Jakarta: Bumi Aksara, 2006.

Arsyad, Azhar. Media Pembelajaran. Jakarta: Raja Grafindo, 2007.

Baumfield, Vivienne Marie, Elaine Hall, dan Kate Wall. Action Research In the Classroom: Penelitian Tindakan Kelas. Diterjemahkan oleh Saifuddin Zuhri Qudsy. Yogyakart: Pustaka Pelajar, 2009.

Djamarah, Syaiful Bahri. Guru dan Anak Didik dalam Interaksi Edukatif. Jakarta: Rineka Cipta, 2000.

Fitria, Happy, Muhammad Kristiawan, dan Nur Rahmat. "Upaya

Meningkatkan Kompetensi Guru Melalui Pelatihan Penelitian Tindakan Kelas.” Abdimas UNWAHAS 4, no. 1 (2019). https://doi.org/10.31942/abd.v4i1.2690.

Indriana, Dina. Mengajar Efektif dengan Media Pengajaran. Yogyakarta: Diandra Kreatif, 2018.

Jana, Padrul, dan Bayu Pamungkas. "Pelatihan Penelitian Tindakan Kelas Bagi Guru SD Negeri Guwosari." Abdimas Dewantara 1, no. 1 (2018): 39-46. https://doi.org/10.30738/ad.v1i1.2289.

Kunandar. Langkah Mudah Penelitian Tindakan Kelas. Jakarta: PT. Rajawali Pers, 2011.

Muslich, Masnur. Melaksanakan PTK Itu Mudah. Jakarta: Bumi Aksara, 2011. . Melaksanakan PTK (Penelitian Tindakan Kelas). Jakarta: Bumi Aksara, 2009.

Nappu, Syamsiarna, Ratna Dewi, dan Herlina Daddi. "Peningkatan Kemampuan Guru dalam Melaksanakan Penelitian Tindakan Kelas." Jurnal Dedikasi 21, no. 1 (2019): 5. https://ojs.unm.ac.id/dedikasi/article/view/9431. 